\title{
Influence of Fresh Chopped Leaves and Dry Leaf Powder of some Horticultural Trees on Controlling Root-knot Nematode, Meloidogyne javanica on Broad Bean
}

Montasser, S.A. ${ }^{\text {; }}$ N.A. Mahmud $^{2}$; $^{\text {*A.F.M. El-Mesalamy }}{ }^{2}$ and M.A.A. Abdel-Mageed ${ }^{2}$

${ }^{1}$ Agric. Zoology and Nematology Dept., Fac. of Agric., Al-Azhar Univ. Cairo.

${ }^{2}$ Agric. Zoology and Nematology Dept., Fac. of Agric., Al-Azhar Univ. Assiut branch.

Email: AnasElmesalamy@yahoo.com

Received on: $27 / 10 / 2019$

Accepted for publication on: 5/11/2019

\section{Abstract}

Fresh chopped and dry leaf powders of china berry(Melia azedarachta), golden chain (Cassia fistula), luciana (Lucaena Leucocephala), poinciana (Poinciana regia) and purple orchid (Bauhinia Variegata) was applied as soil amendments at rates of 5, 10, 15 and $20 \mathrm{~g} / \mathrm{kg}$ soil to control the root-knot nematode, Meloidogyne javanica infecting broad bean cv. Maser-1 under greenhouse conditions. Result revealed that all powder or chopped amendments suppressed population of nematode and fewer root galls per plant were formed special at the highest rates of amendments. All treatments significantly $(\mathrm{P} \leq 0.05)$ decreased nematode criteria when compared to untreated (check). In general, there was a positive correlation between the tested rates and the percentages reduction in nematode parameters higher rates of chopped or dry leaves were caused higher percentage nematode reduction, when compared the whole averages of materials with each other in controlling nematode parameters. Also, almost the treatments of dry leaf powder amendments succeeded in improving the plant growth than unamended soil as evidence in increment of lengths and fresh weights of both shoots and roots. Also, the increase in such parameters of plant growth clear differences according to the type and the amount of materials used.

Keywords: Meloidogyne javanica, broad bean, fresh copped tree leaf, dry leaf powder, root-knot nematode, soil amendment.

\section{Introduction}

The influenced of fresh chopped leaves and dry leaf powder on controlling root-knot nematodes and consequently improving plant growth, voluminous studies had been done on several economic vegetable crops by many workers (Mojtahedi et al., 1991; Montasser et al., 1991; Patel et al., 1994; Kimenju et al., 2008; Ibrahim and Traboulsi, 2009; Montassere et al., 2012; Mouse et al., 2014 and Sowley et al., 2014).

The first report of such a phenomenon by amending soil with chopped pineapple leaves (Ananas comosus L.) to control Meloidogyne spp. in cowpea recorded by (Leinford et al., 1938). Chopped neem leaves when adding to soil infested with Rotylenchulus reniformis yielded the greatest reduction in nematode numbers (Lall et al., 1977). Dry leave powders of Tagets patula, Xanthium straumarium, Verbesina enceloides and Artomesia scopraria produced the greatest reduction in $M$. incognita population and improved plant growth (Sharma et al., 1985). The application of fresh Gliricidia leaves to soil reduced the total nematode populations of Meloidogyne incognita 
and Rotylenchulus reniformis (Duhaylongsod, 1988). The tested dry leaf powders amendments Bauhinia variegate, Cassia fistula, Cassia nodosa, Ceratoni siligua, Dalbergia sisso, Eucalyptus restrate, Ficus nitida, Poinciana regia, Populus nigra, and Sterculia diversifolia significantly reduced the numbers of root galls and the rate of nematode penetration on tomato roots when compared with the untreated control Montasser, (1991). Dry leaf powder of Tagetes erecta and Ricinus commanis Suppressive effect on nematode reproduction as well as improved soybean shoot and root weights Al-Sayed et al., (1992). Dry leaf powder of damsis give the conceder able control of root-knot nematode with increase in growth of sunflower as compared to un-treated check followed by parsley, Indian laburnum, fennel, sweet marjoram and coriander especially at two higher rates of application (Montasser et al., 1999). Tithonia diversifolia, Desmoaium uncinatum, Tagetes minuta, Leucaena leucocephala, and Crotalaria juncea were among the most effective in root-knot nematode suppression when used in rotation with beans. Such as green manure plants reduced the reproductive potential of Meloidogyne spp. (Kimenju et al., 2008). Chopped or ground dry leaves of assa-peixe (Vernonia polyanthes), lemon-grass (Cymbopogon citratus), eucalyptus (Eucalyptus citriodora), castor (Ricinus communis), mango (Mangifera indica) or neem (Azadirachta indica) reduced the gall number, when incorporated into the soil as powder, and maximum nematode suppression occurred in soil amended with neem leaves (61\%)
(Lopes et al., 2011). The application of Azadirachta indica leaf powder gave the highest reduction in root galls and nematode population followed by Cassia siamea, Eucalyptus gigantea and Parkia biglobosa (Chimobekujwo et al., 2013). Minimum gall formation observed in Aegle marmelos and Prosopis cinerarea treated plants and all the tested dry leave powder improved plant growth characters of Coleus forskohlii over control (Soumana and Trivedi, 2015). The aim of this study to control the root-knot nematode of broad been coasted by Meloidogyne gavanica by using fresh chopped leaves and dry leaf powder of some horticulture trees.

\section{Materials and Methods}

Preparation of nematode inoculum.

Two-months-old tomato (Solanum lycopirscon L.) roots infected with populations of Meloidogyne javanica were washed with tap water to remove adhering soil particles, cut into small pieces and the eggs collected according to Hussey and Barker (1973). The extracted eggs were transferred to Baermann trays with soft tissue paper at room temperature to allow egg hatching. After 72 hours, the emerging second stage juveniles were counted under a light microscope and the average number per $\mathrm{ml}$ calculated.

Evaluation of some horticultural trees leaves against root-knot nematode, Meloidogyne javanica infecting broad bean cv. Maser 1 .

Leaves of five trees were tested chinaberry (Melia azedarachta), golden chain (Cassia fistula), luciana (Lucaena Leucocephala), poinciana (Poinciana regia) and purple orchid 
(Bauhinia Variegata). Leaves were collected from trees and dried under shade for 10 days before being pounded with Compactor to make a coarse powder. In the other treatment leaves of trees were collected from trees and finely chopped before add to soil. Tree leaves were applied to the soil at the rate of 5, 10, 15 and 20 gm. per $1 \mathrm{kgm}$ soil. Broad been seeds were planted in $15 \mathrm{~cm}$ diam. Clay pots containing autoclaved sandy clay soil 1: 1 (v: v). After two weeks from planting has infection with 1000 newly hatched larvae of root knot nematode per pot.

Un- inoculated pots served as a control. Four replicates of each of them five treatments with different concentrations compared to untreated (control). All pots were arranged in a randomized block design a greenhouse. All plants were grown during the normal growing seasons at greenhouse temperature of $35 \pm 5 \mathrm{c}, 45$ days after inoculation, all plants were harvested and removed gently, washed in water and the root of each plant was stained in lacto phenol acid fuchsine (Goodey 1963). Eggs of ten randomly selected egg-masses of each root system were also counted by sodium hypochlorite. The rate of nematode reproduction was calculated. The number of juveniles in soil per pot, galls, developmental stages on root, egg-masses per root and number of eggs/ egg mass were counted by Christie \& Perry (1951) and Southey (1964) fresh weights of the root and shoot systems as well as their lengths were determined. Data were subject to analysis of variance (ANOVA) (Gomes \& Gomez, 1984) and means were compared by Duncan multiple - range test (Duncan1955).

\section{Results and Discussion}

A- The effect of dry leaf powders of tree leaves as soil amendment against the root-knot nematode, Meloidogyne javanica on broad bean cv. Maser 1.

The effect of amending soil with dry leaf powders of china berry ( $\mathrm{Me}-$ lia azedarachta), golden chain (Cassia fistula), luciana (Lucaena Leucocephala), poinciana (Poinciana regia) and purple orchid (Bauhinia Variegata) to control the root-knot nematode, Meloidogyne javanica infecting broad bean cv. Maser 1 was studied ander greenhouse conditions. Data presented in Table (1) revealed that all powder amendments suppressed populations of nematodes and fewer root galls per plant were formed special at the highest rates of amendments. Therefore, all amendments of the tested powder tree leaves as soil application significantly reduced the values of root galls per root and nematode reproduction on roots of broad bean cv. Maser 1 when compared with unamended control. Such nematode values gradually decreased with increasing the amended of any of the tested dry leaf powder, Table (1). However, the highest reductions in number of galls and rate of nematode reproduction in soil tested with $20 \mathrm{~g} / \mathrm{kg}$, soil of the highest reduction in the number of galls and rate of nematode reproduction in soil treated with $(20 \mathrm{~g} / \mathrm{kg}$ soil $)$ of china berry, golden chain, luciana, poinciana and only purple orchid 15 and 20 ( 3 and 0.22 ), (5 and 0.16) (3 and $0.09)$, (4 and 0.22) and (7 - 0.22 and 
$5-0.13)$, respectively. There are significantly differences $(\mathrm{P} \geq 0.05)$ in the number of galls per root of broad bean grown in soil amended with such materials at the rate of $(5 \mathrm{~g} / \mathrm{kg}$ soil) was found when compared with those of the other treatments, (Table 1). Also, the nematode final population lower than initial population at rates of 15 and $20 \mathrm{~g} / \mathrm{kg}$ soil amended with china berry, luciana and poinciana with values ( 0.49 and 0.22$),(0.99$ and 0.09$)$ and (0.74 and 0.22$)$ respectively.

Data showed in Table (2) that almost the treatments of dry leaf powder amendments succeeded in improving the plant growth than unamended soil as evidence in increment of lengths and fresh weights of both shoots and roots. Also, the increase in such parameters of plant growth varied greatly according to the type and the amount of materials. Treatments had significant effect on plant growth parameters when compared with treated plants with nematode alone (check) except in luciana at rates of 15 and $20 \mathrm{~g} / \mathrm{kg}$ soil which recorded decrease in shoot and root of lengths and fresh weights. Shoot and root lengths and fresh weights significant increase with china berry $(40.65-68.96-56.73$ and $70.04 \%)$, golden chain $(39.54-46.71-63.47$ and 55.53), luciana (28.49 - $40.49-$ 55.47 and $70.33 \%$ ) and poinciana $(42.42-69.98-60.13$ and $58.32 \%)$ at rate of $5 \mathrm{~g}$. Also, leaf powder of purple orchid had also significant effect at highly rate of application on shoot and root lengths and fresh weights of broad bean cv. Maser $1(36.96-63.37-50.40$ and $51.68 \%)$ compared to plants treated with nematode alone. 
B- The effect of some fresh chopped tree leaves as soil amendment against the root-knot nematode, Meloidogyne javanica infecting broad bean cv. Maser 1.

Chopped same tree leaves used in this study were promising in controlling M. javanica infecting (broad bean cv. Maser 1) and enhancing plant growth criteria (Table 3). The numbers of galls per root, nematode juveniles in soil per pot, nematode developmental stages per root, eggmasses per root, eggs per egg-mass, nematode final population and rate of nematode reproduction differed according to treatment and material used (Table 3). Population of nematode significantly $(\mathrm{P} \leq 0.05)$ increased in untreated pots,all treatments significantly $(\mathrm{P} \leq 0.05)$ decreased nematode criteria when compared to untreated (check). In general, there was a positive correlation between the tested rates and the percentages reduction in nematode parameters. Higher rates of chopped were caused higher percentage nematode reduction. Its lower rates caused lower percentages nematode reduction. When compared the whole averages of materials with each other in controlling nematode parameters, it is evident that, the highest degree of reduction in the nematode infection being recorded in plants treated with $20 \mathrm{~g}$. $/ \mathrm{kg}$. Soil) of chopped leaves of golden chain, poinciana and purple orchid, they recorded in number of galls and rate of nematode reproduction ( 3 and $0.16)$, (3 and 0.13) and (4 and 0.19) respectively. Those treated with a lower rates $(5 \mathrm{~g}$. $/ \mathrm{kg}$. soil) of golden chain, luciana and poinciana chopped leaves recorded the least effect in number of galls and rate of nematode reproduction (28 and 3.48), (24 and $4.86)$ and (25 and 3.35) respectively as compared to untreated control (36 and 10.34). Whereas the reduction in the root-knot nematode, $M$. javanica parameters at rates $(10$ and $15 \mathrm{~g} / \mathrm{kg}$ soil) recorded moderate values in nematode criteria.

Data also in Table (4) revealed that, almost of used treatments recorded significant increase of plant growth when compared with untreated (check) while, at rates of 10 and $15 \mathrm{~g}$ of chinaberry chopped leaves decreased plant growth. The effect of chopped leaves on plant shoot and roots length and fresh weight were classified to three groups: No significant difference between different rates of china berry as applied soil in shoot length, fresh weight and Root weight, luciana in shoots and root lengths, poinciana in shoot lengths and fresh weights and purple orchid in root fresh weight. A significant difference between different chopped trees leaves rates as applied to the soil and the heights increase with the high rate $20 \mathrm{~g}$ recorded (china berry in root lengths, golden chain in shoot and root lengths and fresh weights, luciana and poinciana in root fresh weight, and purple orchid in shoot lengths and fresh weights, Table (4).A significant difference between different chopped trees leaves rates as applied to the soil and the heights increase with the less at rate of $5 \mathrm{~g}$. (luciana in shoot lengths, poinciana and purple orchid in root length. 
Our Results in the study are in keeping of those of (Van Dar Laan, 1956 and Alam et al., 1977 and 1980) who reported that soil amendments with dry leave powders and chopped leaf plants improved the growth of plants and hence increase the tolerance and resistance against plant parasitic nematodes. Some materials release compounds toxic to nematodes preformed like phenol, tannin azdirachtin, salannin, nimbin, nimbidin, thionemone, meliantol and ricinin (Mian et al., 1983; Rich et al., 1989; Herrera, 1997 and Akhtar and Malik, 2000) or derived from the decomposition process in soil like ammonia, nitrites, hydrogen sulphid and thiophenes (Rodringuez-Kabana et al., 1981; Rodringuez-Kabana, 1986 and Ekatorini and Prosser, 2003). Soil amendments may also provide afavourable substrate for the sustenance of soil microfauna and microflora (Sayre et al., 1964) which can include direct predators (micro-arthropods) or parasites (fungi, bacteria) of nematodes or which suppress soil nematode population indirectly through the production of enzymes, emelys, chitinase, collagenase, kerasstase and elastase which disintegrate nematode cuticle (Rodriguez-kabana et al, 1983 and Galper et al., 1990) or toxic metabolites, such as antibiotic of bacteria origin (Mahdy, 2002 and Schosser et al., 2006). Bio-fumigationwas defending as a process of liberation of secondary volatile or not-volatile phytochemicals with nematicidal properties were released during decomposing of materials or animal products. A number of toxic gas products (e.g. thiocyanate and isothiocyanate) are known to be released from these compounds during decomposition (Brown et al., 1991; Angus et al., 1994; Morra and Kirkegaard, 2002; Lopez-Perez et al., 2005; and Roubtsov et al., 2007).

\section{References}

Akhtar, M. and Malik, A. (2000). Rols of soil amendments and soil organism in the biological control of plant parasitic nematodes. Bioresource Technology, 74: 35 - 47.

Alam, M.M.; Ahmad, M. and Khan, A.M. (1980). Effect of organic amendments on the growth and chemical composition of tomato, eggplant and chilli and their susceptibility to attack by Meloidogyne incognita. Plant and Soil, 57: $231-236$.

Alam, M.M.; Siddiqui, S.A. and Khan, A.M. (1977). Mechanism of control of plant parasitic nematodes as a result of the application of organic amendments to the soil III. Role of phenols and amino acids in host roots. Indian J. Nematol., 7: $227-231$.

Al-Sayed, A.A.; Ahmed, S.S. and Abdelhameed, S.H. (1992). Influence of decomposing dry leaf powders on Rotylenchulus reniformis and growth response of soybean. Annals of Agric. Sci. Moshtohor, 30: $615-620$.

Angus, G.F.; Gardner, A.; Kirkegaard, J.A. and Desmarchelier, J.M. (1994). Biofumigation: Isothiocyanates relased from brassica roots inhibit growth of the take-all funus. Plant and Soil, 162: 107 112.

Brown, P.D.; Morra M.J.; Mcffrey, J.P.; Aduld, D.1. and Williams, L. (1991). Allelochemichals produced during glucosinolate degradation in soil. J. Chem. Ecol., 17: 2021 2034.

Chimobekujwo, I.B.; Bukar, A.M. and Channya, F.K. (2013). Manage- 
ment of root-knot nematodes (Meloidogyne incognita) on cowpea with plant extracts. Pertanika Trop. Agric. Sci., 36: $275-284$.

Chrisitie, J.R. and Perry, G.V. (1951). Removing nematodes from soil proc. Helm. Soc. Wash., 18: $160-$ 168.

Duhaylongsod, R.D. (1988). Population of root-knot and reniform nematodes in soil amended with fresh and composted organic materials. Int. Nematol. Network Newsl, 5: 24-26.

Duncan, D.B. (1955). Multiple range and multiple $\mathrm{F}$ tests. Biometrics, 11: 142.

Eisenhauer, N.; Cesarz, S.; Koller, R.; Worm, K. and Reich, P.B. (2012) Global change below ground: impacts of elevated $\mathrm{CO} 2$, nitrogen and summer drought on soil food webs and biodiversity. Global Change Biology, 18: 435-447

Ekatorini, R. and Prosser, W. (2003). Screening of mustards and other Brassicas for nematode control. J. Nematol., 28: 648 - 654 .

Galper, S.; Cohn, E.; Spiegel, Y. and Chet, I. (1990). A collagenolytic Fungus, Cunninghamellaelegans for biological control of plant parasitic nematodes. J. Rev. Nematol. 13: $67-71$.

Gomez, K.W. and Gomez, A.A. (1984). Statistical procedures for agricultural research $2^{\text {nd }}$ Ed. John Wiley and Sons inc, New York 680p.

Goodey, J.B. (1963). Laboratory methods for work with plant and soil nematodes. Ministry of Agric., Fisheries and Food. London Tech. Bull., 2: 72 pp.

Herrera, S.I.C. (1997). Effect of legume cover crops on the control of phytoparasitic nematodes of coffee. Memoirs of the X VIII Latin American Symposium of coffee production, Costa Rica II CA-
Miscellaneous Publication Al-Sc. $97-05,387-391$.

Hussey, R.S. and Barker, K.R. (1973). A comparison of methods of collecting inocula of Meloidogyne spp. including a new technique. Plant Disease Reporter, 57: 1025-1028.

Ibrahim, S.K. and Traboulsi, A.F. (2009). The impact of solarisation integrated plant bio-fermentation on root-knot nematodes. Lebanese Sci. J., 10: $59-69$.

Kimenju, J.W.; Kagundu, A.M.; Nderitu, J.H.; Mambala, F.; Mutua, G.K. and Kariuki, G.M. (2008). Incorporation of green manure plants into bean cropping systems contribute to root-knot nematode suppression. Asian J. Plant Sci. 7: 404 408.

Kunenju, J.W.; Kagundu, A.M.; Nderitu, J.H.; Mambala, F.M. and Mutua, G.K. (2007). Use of green manure plants in cropping systems to suppression root-knot nematodes. African crops Sci. Conf. Proc., 8: $1083-1085$.

Lall, A.; Yadav, B.S. and Nanduana, R.P. (1977). Effect of chopped leaves of various plants and sewage on the plant growth and reniform nematode Rotylenchulus reniformis. Indian J. Mycol and Plant Pathol., 78: 68 - 69.

Linford, M.B.; Yapp, F. and Oliveira, J.M. (1938). Reduction of soil populations of root-knot nematode during decomposition of organic matter. Soil Science, 45: 127-140.

Lopes, E.A.; Ferraz, S.; Ferreira, P.A.; Freitas, L.G. and DallemoleGiaretla (2011). Soil amendment with chopped or ground dry leaves of six species of plants for the control of Meloidogyne javanica in tomato under greenhouse conditions. Ciencia Rural, 41: 935 - 938.

Lopez-Perez, J.; roubtsova, T. and Ploeg, A. (2005). Effect of three plant res- 
idues and chicken manure used as bio-fumigants at three temperatures on Meloidogyne incognita infestation of tomato in greenhouse experiments. J. Nematol., 37: 489494.

Mahdy, M.E. (2002). Biological control of plant parasitic nematodes with antagonistic bacteria on different host plants. Ph. D. Thesis, Bonn Univ. Germany, $171 \mathrm{p}$.

Mian, I.H.; Godoy. G.; RodriguezKabana, R.; Shelby, R.A. and Morgan- Jones, G. (1983). Chitin amendments for control of Meloidogyne arenaria infested soil. Nematropica, 12: $71-74$.

Mojtahedi, H.; Santo, G.S.; Hang, A.N. and Wilson, J.H. (1991). Suppression of root-knot nematode population with selected rapseed cultivars as green manure. J. Nematol., 23: 176-178.

Mojtahedi, H.; Santo, G.S. Inham, R.E. (1992). Suppression of Meloidogyne chitwoodi with Sudan grass cultivars as a green manure. J. Nematol., 25: 303 - 311.

Montasser, S.A. (1991). Effect of decomposing dry leaf powders on the incidence of root galls and the growth of tomato. Annals of Agric. Sci. Moshtohor, 29: 1739 - 1750.

Montasser, S.A.; Ahmed, M.M. and Mostafa, M.A. (1999). Effect of dry leaf powders of some medicinal and aromatic plants as soil application in controlling the root-knot nematode, Meloidogyne incognita in relation to the growth of sunflower plants. Minufiya J. Agric. Res., 24: 757 - 774.

Montasser, S.A.; Mahrous, M.E.; and Al-Sayed, A.A. (1991). Effect of green manure as soil organic amendments in the controlling the root-knot nematode Meloidogyne incognita on potato. Egypt. J. Appl. Sci., 6: 617 - 625.
Montasser, S.A.; Mostafa, M.A. Anany, A.E. and Bashandy, A.S. (2012). Influence of decomposing of some green leaf weeds on sunflower plants infected with Meloidogyne incognita. Egypt J. Agronematol., 1: $193-204$.

Morra, J. and Kirkegaard, J.A. (2002). Isothiocy Isothiocyanate release from soil-incorporated Brassica tissues. Soil Biol. Biochem., 34: 1683 - 1690 .

Mouse, E.M.; Mahdy, M.E. and YounisDalia, M. (2014). Efficacy of chopped fresh leaves of some plants on controlling Meloidogyne javanica infecting tomato plants. Egyptian J. plant Protection, 9: 21 $-29$.

Patel, H.R.; Patel, D.J.; Patel, C.C. and Thakar, N.A. (1994). Effectivity of Clerodendron inerme, Catharanthus roseus and Azolla pinnaia for management of root-knot nematodes on okra. Pak. J. Nematol., 12: $95-98$.

Rich, J.R.; Rahi, G.S.; Oppermann, C.H. and Davis, E.1. (1989). Influence of the castor bean (Ricinus communits) lectin (ricin) on mortality of Meloidogyne incognita. Nematropica, 19: 99 - 103.

Rodriguez-Kabana, R.; King, P. S.; Pope, M. H. (1981). Combinations of Anhydrous Ammonia and Ethylene Dibromide for Control of Nematodes Parasitic of Soybeans. Nematropica, 11: $27-41$.

Rodriguez-Kabana, R. (1986). Organic and inorganic nitrogen amendments to soil as nematode suppressants, J. Nematol., 18: 129 - 135.

Rodriguez-Kabana, R.; Godoy, G.; Morgan-Jones, G. and Shelby, R.A. (1983). The determination of soil chitinase activity. Conditions for assay and ecological studies. Plant and Soil, 75: 95 - 106.

Roubtsov, T.; López-Pe'rez1, J.; Ed- 
wards, S. and Ploeg, A. (2007). Effect of broccoli (Brassica oleracea) tissue, incorporated at different depths in a soil column, on Meloidogyne incognita. J. nematol., 39: $11-117$.

Sayre, R.M.; Patrick, Z.A. and Thorpe, H.J. (1964). Substances toxic to plant-parasitic nematodes in decomposing plant residues. Phytopathol., 54: 905.

Schosser, B.; Hauser, S. and Sikora, R.A. (2006). Suitability of Pueraria phaseoloides, Chromolaenaodorata and Ti thoniadiversifolia as insitu mulch for nematode management in musa cropping systems. Commun. Agric. Applied Biol. Sci., 71: 675 687.

Sharma, C.; Trivedi, P.C. and Tiagi, G. (1985). Effect of green manuring on population of Meloidogyne incognita on musk-melon. Int. Nematol. Network Newsl., 2: 7 - 9.
Soumana, T.L.D. and Trivedi, P.C. (2015). Sustainable use of medicinal plants to control Meloidogyne incognita. A strategy to fight rootknot disease of crops in Rajasthan, India. World J. Pharmacy and Pharmaceutical Sci., 4: 819 - 829 .

Southey, I.F. (1964). Laboratory methods for work with plant and soil nematodes. Tech . Bull. min. agric. fish. Fd., No 2(5 $5^{\text {th }}$ ed) $148 \mathrm{pp}$.

Sowley, E.N.K.; Kankam, F. and Adomako, J. (2014). Mangment of root-knot nematode Meloidogyne spp. on sweet pepper (Capsicum annuиm L.) with moringa (Moringa oleifera Lam.) leaf powder. Arch. Phytopathl. Plant Prot., 47: 1531- 1538.

Van Der Laan, P.A. (1956). The influence of the organic manuring on the development of the potato rooteelworm, Heterodera rostochiensis. Nematologica, 1: 112- 125. 
دراسة تأثير أوراق بعض الأثجار البستانية الجافة و الطازجة علي نيماتودا تعقدا

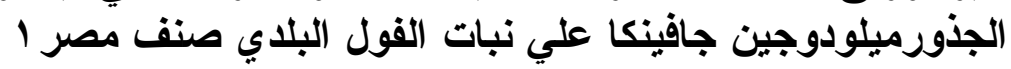

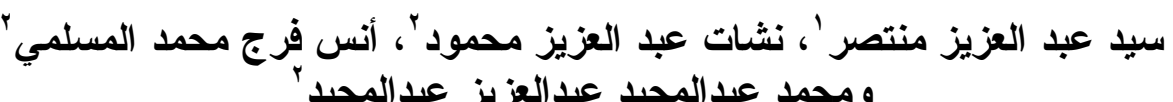

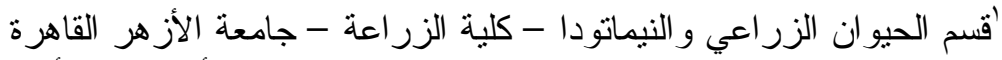

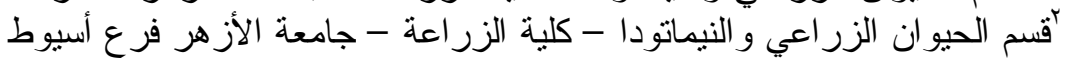

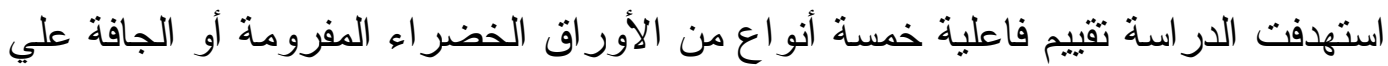

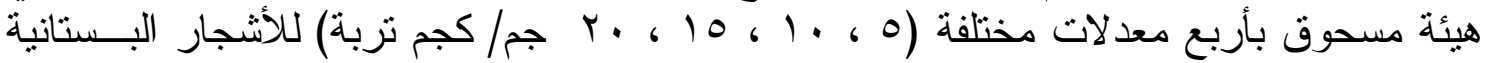

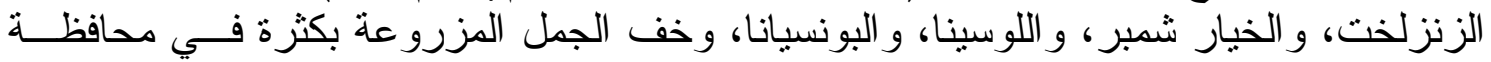

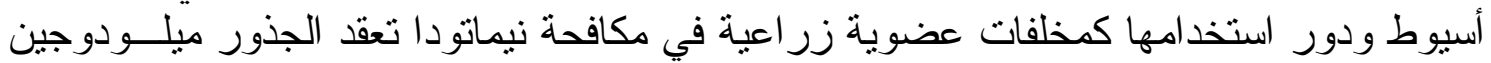

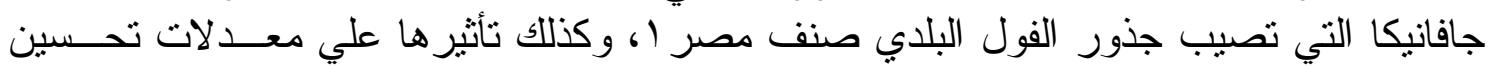
نو النباتات المصابة.

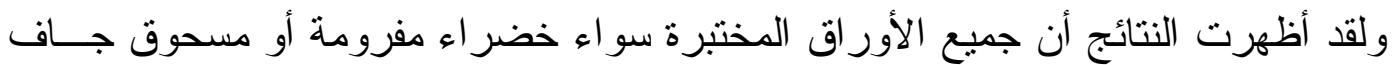

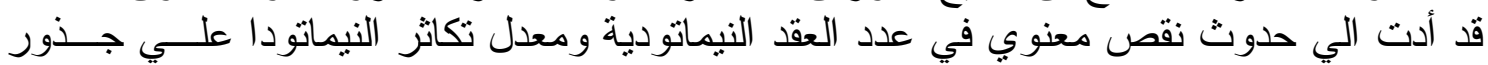

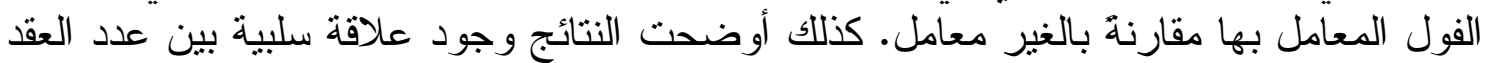

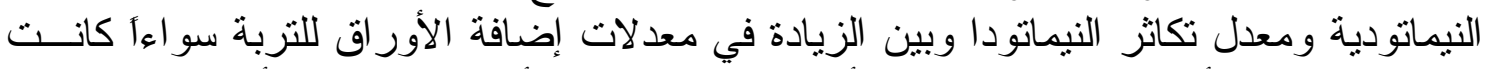

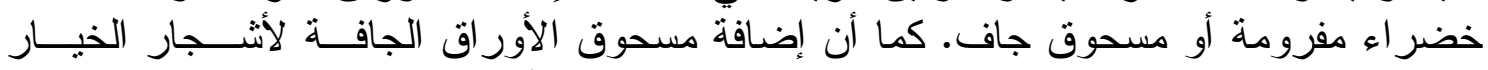

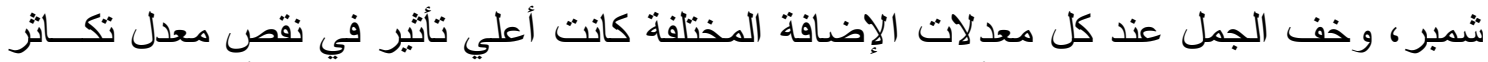

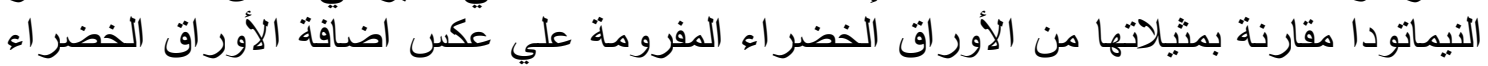

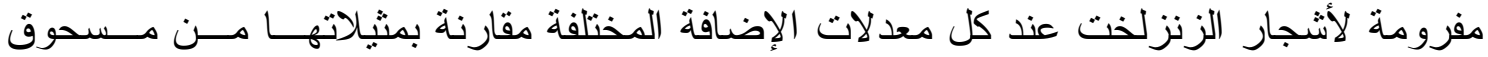

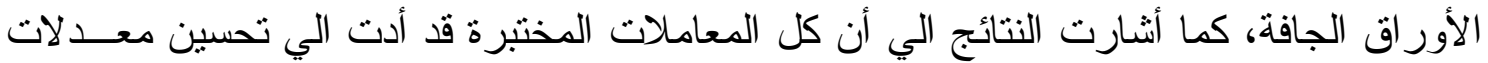

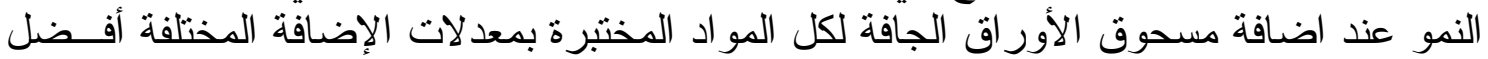

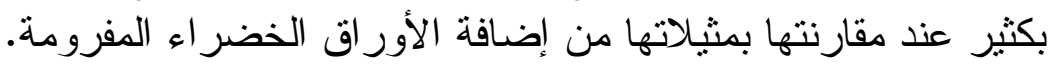

